\title{
UDC 658.52
}

\section{MECHANICAL PROPERTIES OF HEAT-RESISTANT SUPERALLOY INCONEL 718 OBTAINED BY SELECTIVE LASER MELTING AND HEAT TREATMENT UNDER DIFFERENT LOAD DIRECTIONS}

\author{
Sergey Adjamskiy ${ }^{1,2}$; Ganna Kononenko ${ }^{2,3}$; Rostislav Podolskyi ${ }^{2,3,4}$
}

\author{
${ }^{1}$ Oles Honchar Dnipro National University, Dnipro, Ukraine \\ ${ }^{2}$ Additive Laser Technology of Ukraine LLC, Dnipro, Ukraine \\ ${ }^{3} Z$. I. Nekrasov Institute of Iron and Steel of the NAS of Ukraine, \\ Dnipro, Ukraine \\ ${ }^{4}$ National Metallurgical Academy of Ukraine, Dnipro, Ukraine
}

\begin{abstract}
Summary. Additive manufacturing is a promising modern direction that allows quickly and with high accuracy layer-by-layer manufacture of complex-shaped products using a computer model from almost any metal powders. This work is devoted to the study of the influence of specimen orientation during 3-D printing and heat treatment modes on the mechanical properties of specimens made of Inconel 718 heat-resistant nickel alloy manufactured using SLM technology. In the study of the position of the specimen during printing, it was found that the strength indicators are slightly higher for vertical specimens (up to 9\%), and the plasticity is lower on average by 20\%. After standard heat treatment, which consists of two stages (quenching and aging) with cooling in quiet air, the strength values of vertically and horizontally constructed specimens are very close (the difference is up to $3 \%)$.The plasticity values for the horizontal position of the specimen when printing are $10 \%$ and $30 \%$ higher. According to macrogeometry, the specimens under study have cup fracture; according to microfractors, it was established that the fracture mechanism is viscous and quasi-brittle. In the initial state, which is formed by 3-D printing, there were signs of viscous fracture: the crack propagates mainly by separating the metal in planes that do not coincide with the crystallographic planes of the sections, mainly the fracture surface in the form of pits microdepressions on the fracture surface. representing the exposed surfaces of the microvoids formed during the plastic flow of the metal. In the study of the metal of the test specimens in the polished state, it was found that specimens No. 1-5 had high integrity (low porosity), a small amount of oxide inclusions was observed. The study found that the presence of defects in the form of micropores did not lead to a significant reduction in the mechanical properties of the test samples.
\end{abstract}

Key words: SLM technologies, Inconel 718, heat treatment, specimen orientation, microfractogram, mechanical properties.

Introduction. Additive production is a promising modern area, which opens new opportunities for the developing complex-shaped metal products for different purposes [1-4].

In recent years the technology of Metal Powder Laser Melting (SLM, DMLS, etc.) has been the most widespread - a technology of laser melting of metal powder, which allows to quickly accurately, layer by layer, produce complex products by a computer model from almost any metal powder [1, 3, 6-7].

SLM technology is used to make irregular-shaped parts, often associated with internal channels, with thin walls for aircraft and space technology, so it is very important to ensure their high quality [1-3, 5-9]. The main problems to assure high quality products using SLMtechnology are porosity, hot cracking, anisotropy, surface roughness, providing the necessary microstructure of the synthesized material $[3,5]$. 
A typical metal microstructure after the end of the construction process turns to be dispersed dendritic and cellular structures of the $\gamma$-phase within the melt baths of single tracks, as a result of overlapping of which a part is created in layers (Fig. 1). As it is shown in Fig. 1, the microstructure depends on the orientation of the specimen and, as a result, due to the direction of applying the load in relation to the specimen construction the mechanical properties may depend.
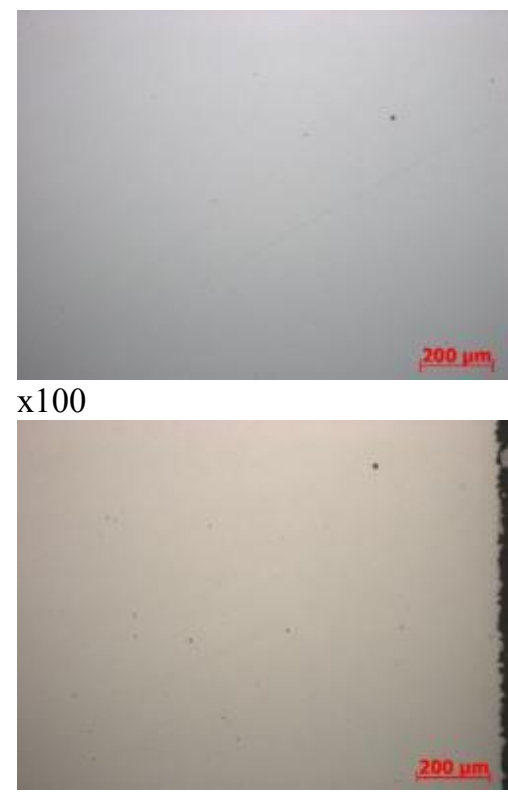

$\mathrm{x} 100$
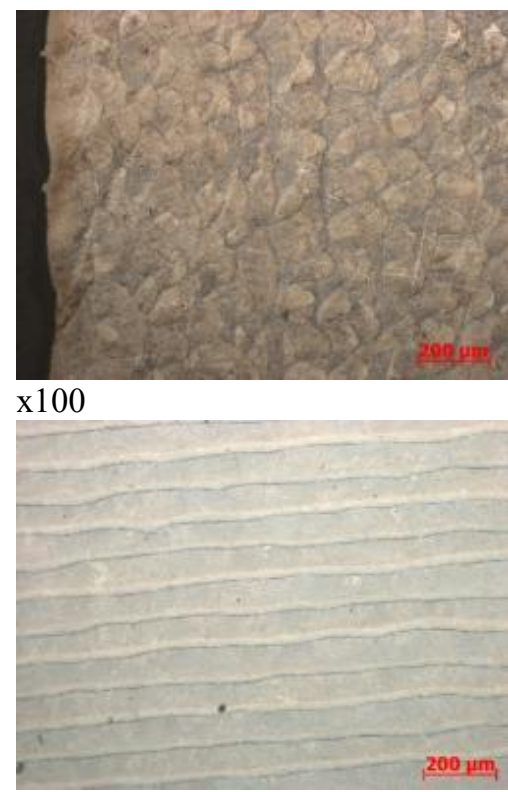

$\mathrm{x} 100$
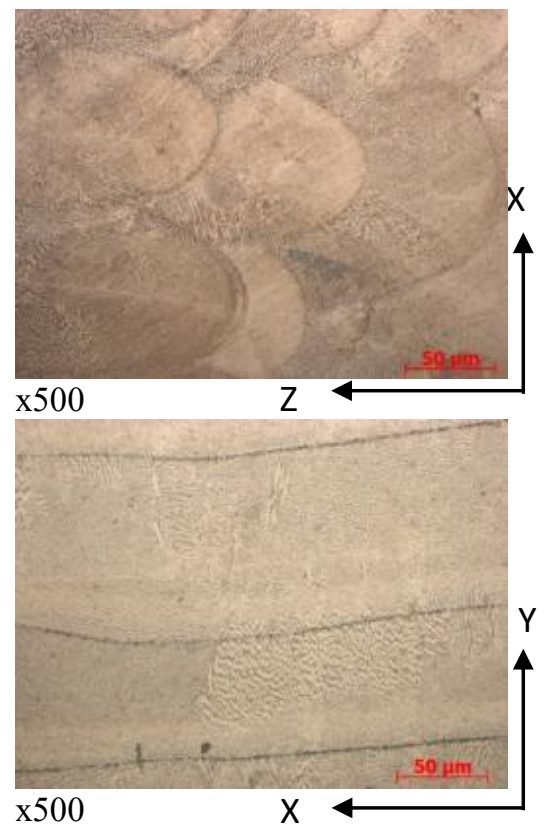

Figure 1. Microstructure of specimen for tensile tests in different planes relative to the position when printing in the initial state

Heat treatment is used to increase the uniformity and the level of the range of mechanical properties. Heat treatment INCONEL 718 has two stages: high-temperature annealing of the solution with cooling to room temperature and aging. As a result of heat treatment, the secondary phases (for example, $\gamma$ 'and $\gamma$ ") in the metal matrix are separated, which leads to the strengthening of the material. Separation of the nickel-aluminum, nickel-titanium and nickelniobium phases is caused by aging in the temperature range of $815-600^{\circ} \mathrm{C}$. The key to the heat treatment process is that these refractory components are completely soluble at high temperatures (i.e. completely soluble in the matrix), otherwise aging will not lead to maximum strength. It is known about the study of options for changes in temperature and holding duration while processing $[10,11]$. The possibility of eliminating the of high-temperature annealing for products made of INCONEL 718, using SLM technology, was also investigated, since crystallization and cooling in such production are realized at high speeds [12].

INCONEL 718 alloy is characterized by a fairly low speed of diffusion processes, so to achieve maximum strength requires many hours of aging. This property makes it possible to weld this material without hardening during cooling. In the process of heat treatment after hightemperature exposure, cooling in water is often used to fix the solid solution, but this operation requires additional equipment. The easiest to implement is cooling in calm air. This research is devoted to the study of the influence of the specimen orientation during printing and heat treatment modes on the mechanical properties of specimens made of heat-resistant nickel alloy INCONEL 718, made by SLM-technology.

Objectives of the research. The research deals with the influence of the specimen orientation during printing and heat treatment modes on the mechanical properties of specimens made of heat-resistant nickel alloy INCONEL 718, produced by SLM-technology. 
Material and methods of research. Materials for the research were specimens for tensile tests of INCONEL 718 alloy, manufactured on LLC «Additive Laser Technology of Ukraine» equipment by SLM-technology. All specimens were printed by identical modes, and were placed on the platform in horizontal and vertical position (Fig. 2). Then the specimens were subjected to heat treatment. In the studies, heat treatment differed in cooling conditions after high-temperature heating: in water and air (Table 1).

Tests to determine the mechanical properties were performed in accordance with ISO 6892 on an INSTRON test machine.

The microstructure was studied on the optical microscope AXIOVERT 200M MAT, the specimens fracture after testing was investigated on an electron microscope PEM 106.

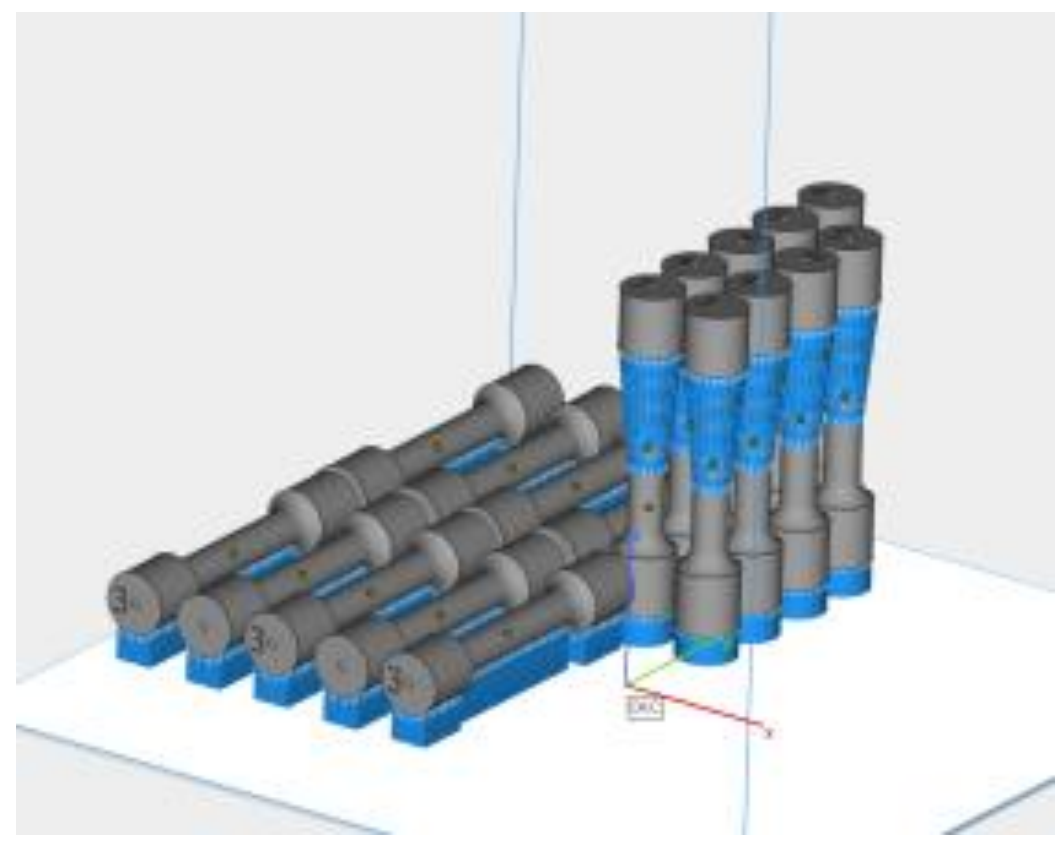

Figure 2. Location of specimens on the platform

Table 1

Modes of heat treatment of test specimens

\begin{tabular}{|c|l|}
\hline Marking & \multicolumn{1}{c|}{ Condition } \\
\hline 1 & Raw (horizontal) \\
\hline 2 & $\begin{array}{l}\text { Mode 1: holding for } 1 \text { hour at } 980^{\circ} \mathrm{C} \text {, air cooling to ambient temperature, } \\
\text { holding for } 8 \text { hours at } 720^{\circ} \mathrm{C} \text {, cooling with an oven to } 620^{\circ} \mathrm{C} \text {, holding at } 620^{\circ} \mathrm{C} \\
\text { for } 8 \text { hours (horizontal) }\end{array}$ \\
\hline 3 & $\begin{array}{l}\text { Mode } 2: \text { holding for } 1 \text { hour at } 980^{\circ} \mathrm{C} \text {, water cooling to ambient temperature, } \\
\text { holding for } 8 \text { hours at } 720^{\circ} \mathrm{C}, \text { cooling with an oven to } 620^{\circ} \mathrm{C}, \text { holding at } \\
620^{\circ} \mathrm{C} \text { for } 8 \text { hours (horizontal) }\end{array}$ \\
\hline 4 & $\begin{array}{l}\text { Mode } 2: \text { holding for } 1 \text { hour at } 980^{\circ} \mathrm{C} \text {, water cooling to ambient temperature, } \\
\text { holding for } 8 \text { hours at } 720^{\circ} \mathrm{C}, \text { cooling with an oven to } 620^{\circ} \mathrm{C} \text {, holding at } 620^{\circ} \mathrm{C} \\
\text { for } 8 \text { hours (vertical) }\end{array}$ \\
\hline 5 & $\begin{array}{l}\text { Mode } 1: \text { holding for } 1 \text { hour at } 980^{\circ} \mathrm{C}, \text { air cooling to ambient temperature, } \\
\text { holding for } 8 \text { hours at } 720^{\circ} \mathrm{C}, \text { cooling with an oven to } 620^{\circ} \mathrm{C}, \text { holding at } \\
620^{\circ} \mathrm{C} \text { for } 8 \text { hours (vertical) }\end{array}$ \\
\hline
\end{tabular}


Table 2

The results of tensile tests of the test specimens

\begin{tabular}{|c|c|c|c|c|c|c|}
\hline Marking & Mode & $\begin{array}{c}\text { Orientation } \\
\text { along axis Z }\end{array}$ & $\sigma_{\mathrm{B}}, \mathrm{MPa}$ & $\sigma_{0,2}, \mathrm{MPa}$ & $\delta_{5}, \%$ & $\Psi, \%$ \\
\hline 1 & $\begin{array}{c}\text { No heat } \\
\text { treatment }\end{array}$ & Hor. $90^{\circ}$ & 1066,3 & 755,0 & 25,6 & 34,9 \\
\hline 2 & 1 & Hor. $90^{\circ}$ & 1394,4 & 1121,4 & 18,8 & 34,9 \\
\hline 3 & 2 & Hor. 90 & 1404,7 & 1153,9 & 14,0 & 18,6 \\
\hline 4 & 2 & Vert. $0^{\circ}$ & 1414,9 & 1185,6 & 12,6 & 13,7 \\
\hline 5 & 1 & Vert. $0^{\circ}$ & 1517,2 & 1181,9 & 15,7 & 25,1 \\
\hline ASTM B637 & $\begin{array}{c}\text { After heat } \\
\text { treatment }\end{array}$ & & $\geq 1275$ & $\geq 1043$ & $\geq 12$ & $\geq 15$ \\
\hline
\end{tabular}

Results of the research. In after heat treatment condition according to mode 2 (with cooling in water), the strength of vertically and horizontally constructed specimens is very similar (the difference is up to $3 \%$ ). Plasticity values for the horizontal specimen when printing are higher (10\% and 30\% for relative elongation and relative narrowing, respectively).

In the after heat treatment state according to mode 1 (air-cooled) for the specimen in the vertical position, the tensile strength is slightly higher (up to 9\%) compared to the horizontal specimen. Herewith, for the specimen placed horizontally when printing, the elasticity is higher ( $16 \%$ and $28 \%$ for relative elongation and relative narrowing, respectively).

Thus, when studying the influence of the specimen position during printing on the mechanical properties after heat treatment, it was found that the strength is slightly higher for vertical specimens (up to 9\%), and the plasticity is lower by an average of $20 \%$.

When analyzing the effect of heat treatment on the properties of the studied specimens, it was found that for horizontal ones heat treatment mode 1 caused the increase in strength by $30 \%$ and yield strength by $35 \%$ as well as brought to decrease in relative elongation by $27 \%$, the relative narrowing was not affected by heat treatment, compared to the initial state after construction by SLM-technology.

Compared with the initial no-heat treatment state, heat treatment according to mode 2 led to increase in the yield strength by $32 \%$, in yield limit - by $53 \%$ and to a decrease in ductility by $45 \%$.

While estimating the impact of the heat treatment modes on the mechanical properties, we can see that after treatment in mode 1 (air cooling) the relative elongation and relative narrowing is higher by $25 \%$ and $47 \%$, respectively, than after treatment in mode 2 (water cooling). The strength limit is not affected by the change of cooling conditions at the first stage of heat treatment; the difference is less than $1 \%$.

Thus, for horizontally located specimens, heat treatment can significantly increase the strength properties; when cooled after high-temperature heating in air, the plasticity decreases not as intensely as after heat treatment with water cooling after the first stage of treatment.

Figure 3 shows the fractograms of the fracture surface of studied specimens after tensile tests.

The study of fractures makes it possible to conclude that: the type and nature of the metal fracture based the metal quality characteristics; identify the structural elements of the fracture surface that differ from the optimal fracture structure; structural defects that lead to reduced properties; macrocontinuities that are present in the metal (flocs, voids, delaminations); the size of dendrites, liquation inhomogeneities; enables to find correlation with the microstructure. For metal products made by SLM technology, the development of cracks in the destruction of the main microstructural elements may be affected by such parameters as layer, the size of the melt 
bath of a single track, the size of dendrites, grain size, voids, oxide inclusions. Figure 3 shows macrofractograms of the test specimens tensile fracture surface after testing.

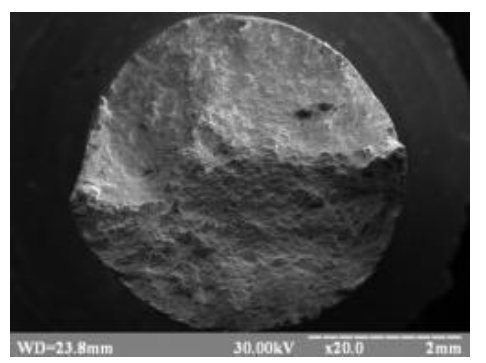

1

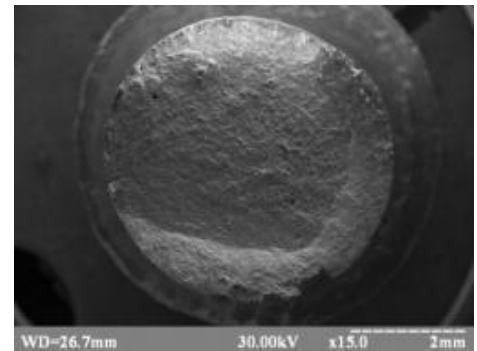

4

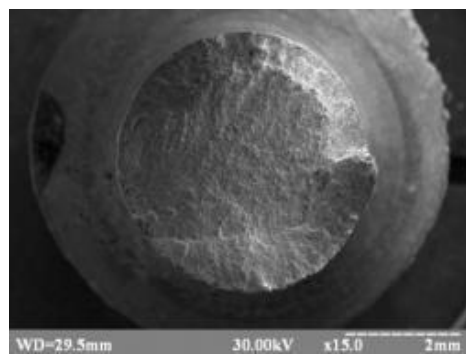

2

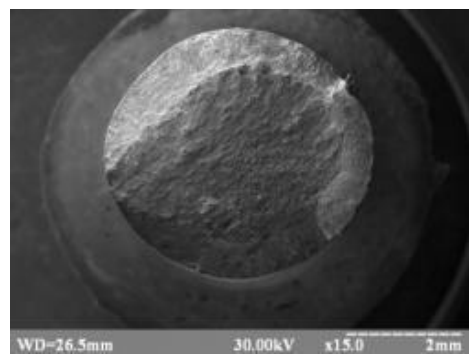

3

Figure 3. Macrofractograms of the studied specimens

According to macrogeometry, the studied specimens have a cup fracture, in which the fracture surface is characterized by the presence of a central area with a rough matte surface perpendicular to the direction of stretching, and obliquity with a smoothed surface inclined at the angle of $30-60^{\circ}$. Formation of such a macrorelief is due to the gradual change of the type of stress state when moving from specimen centre to its periphery. Formation of the cup is associated with necking in the deformed specimen, which causes significant lateral and axial stresses in the center of the specimen. As a result of change of the stress-strain state when the crack approaches the specimen surface, it changes its direction towards the maximum tangential stresses creating the lateral obliquities. Presence of lateral obliquities on the fractures (cup) edge is cheracteristic to macro-viscous fatique.

According to the fracture mechanism, fatigues can be brittle, quasi-brittle or viscous. However, this classification is conventional, mainly due to the heterogeneity of the fatigue structure, which, in turn, is caused by the heterogeneity of the structure and properties of the material, changes in the deformed and stressed state of the material during crack propagation and changes in internal load conditions during failure. Similarly, the cup fracture of the studied specimens is the combination of two fracture mechanisms - narrow in the central part and quasi-brittle on the lateral obliquities (Fig. 4-8).

In the initial state, which is formed by 3-D printing (specimen 1), there were signs of viscous fracture: the crack propagates mainly by separating the metal in planes that do not coincide with the crystallographic planes of the sections, mainly the fracture surface is holeshaped - microconcavities on the fracture surface, which are open surfaces of microvoids formed during the yielding flow of metal. The centre of the microvoids can be the particles of non-metallic inclusions or secondary phases, microcontinuities at the boundaries of grains, subgrains and shear planes. It is implied that viscous fracture begins with the formation of microdrugs and microcavities in areas that prevent trom the deformation continuity (grain boundaries, subgrains, clusters of dislocations, etc.). With further load, the microvoids grow and combine into a common fracture surface - fratugues by pulling the jumpers. Fan orientation 
of the pits visible at high magnifications in the study of specimen 1 demonstrates connection with microstructure (Fig. 1 a).
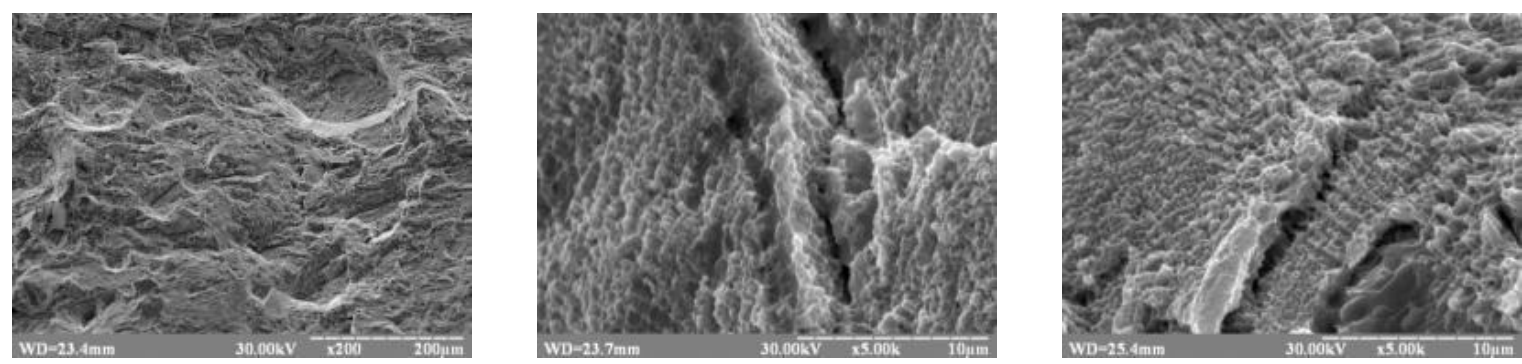

Figure 4. Structure of the fracture surface of specimen1 (horizontal, without heat treatment) after tensile tests

Analysis of the fracture surface of specimen 2 showed signs of a mixed fracture mechanism. In the central part of the specimen the signs of narrow fracture can be seen - areas with pits, ridges formed as a result of plastic yield of metal, development of intragrain crack. When proceeding from the central part of the horizontal surface to the inclined section, the protrusions formed when the propagation of the crack front during the change of the stress state was stopped were observed.

When analyzing the fracture surface of the specimen 3 areas with signs of viscous fibrous fracture and areas of quasi-brittle fracture with facets of quasi-chipping were observed a relatively flat area of fracture, characteristic of wich is that along with signs of brittle fracture it has the signs of plastic deformation (ridges), with pit-shaped or other specific relief. At high magnifications, areas with pits and flat areas with microwaves were detected. Specimen 4 has even smaller relief depth, more fracture surface area has signs of quasi-brittle fracture.

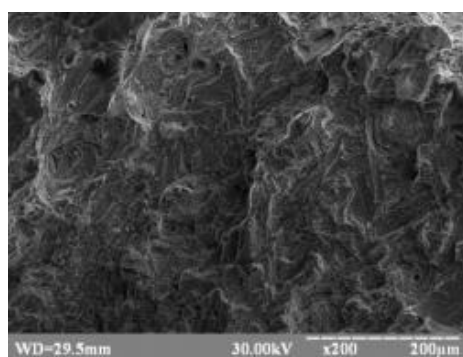

a

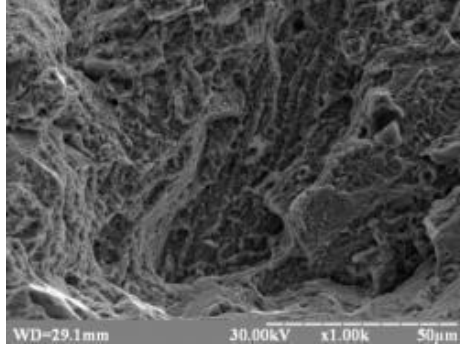

b

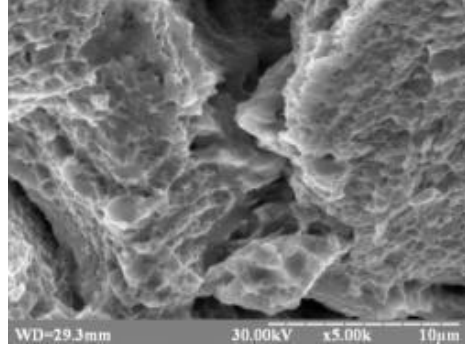

C

Figure 5. Microfractograms of sprcimen 2 (horizontal, heat treatment according to mode 1) after tensile tests

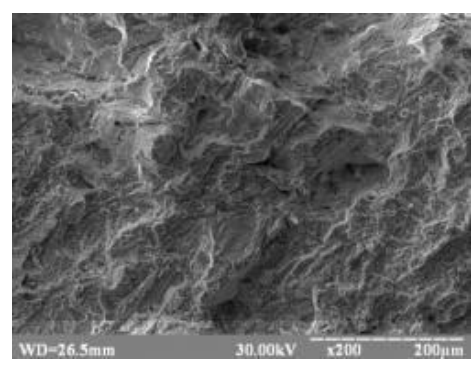

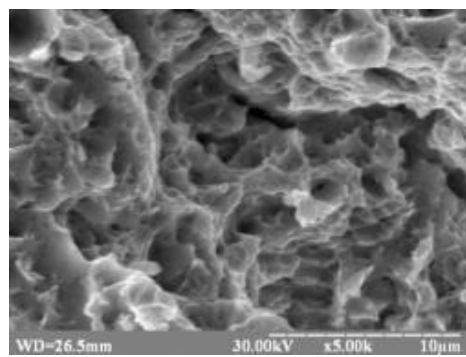

b

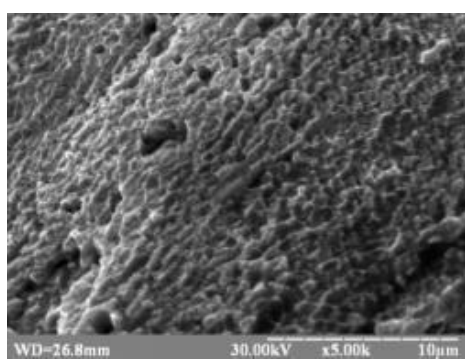

c

Figure 6. Microfractograms of specimen 3 after tensile tests 


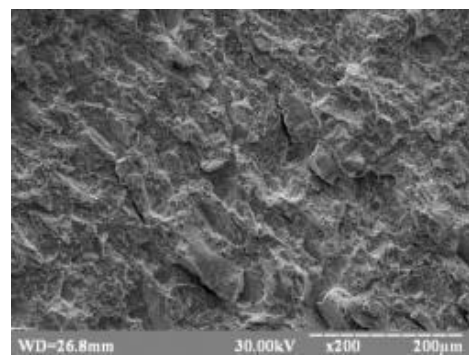

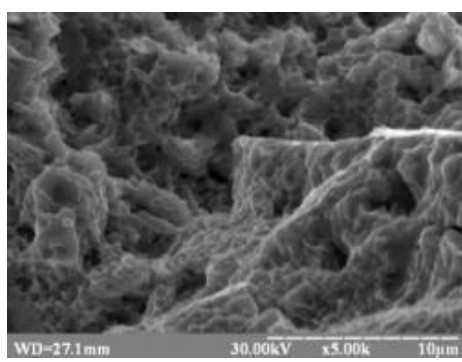

b

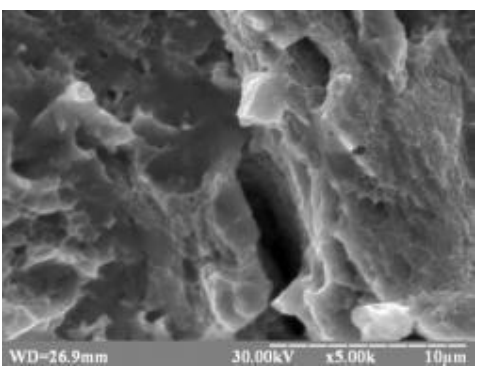

c

Figure 7. Microfractograms of specimen 4 after tensile tests

The analysis of the fracture surface of specimen 5 revealed round defects arranged linearly with a certain periodicity. While studying these structural elements at high magnifications, it was found that they have a relief on the surface formed as a result of the deformation yield of the metal during the test and microcracks. However, the total surface of the fracture had a deep developed relief, large proportion of the area had viscous fracture pits, the crack developed along the complex trajectory.

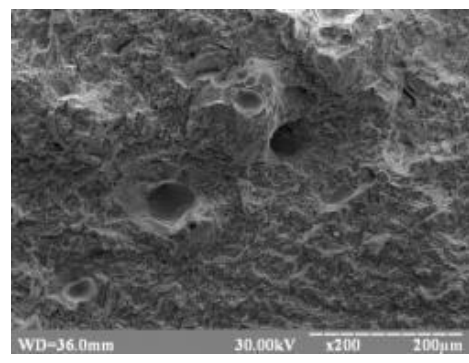

a

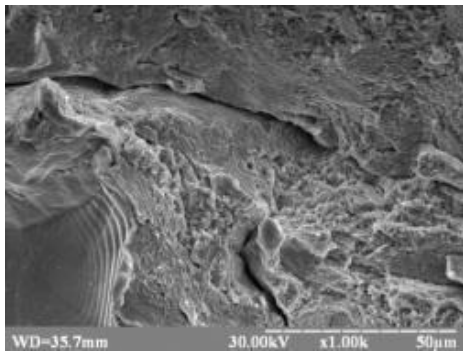

d

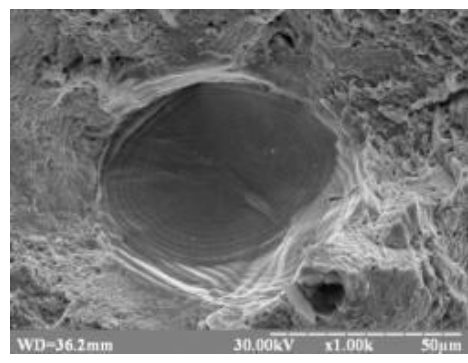

$\mathrm{b}$

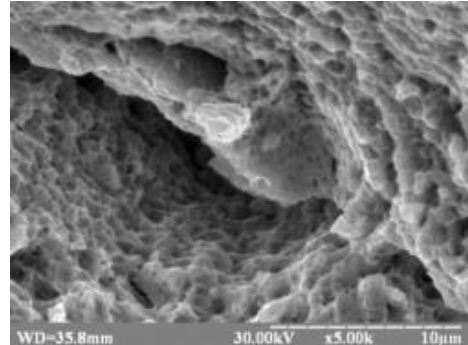

e

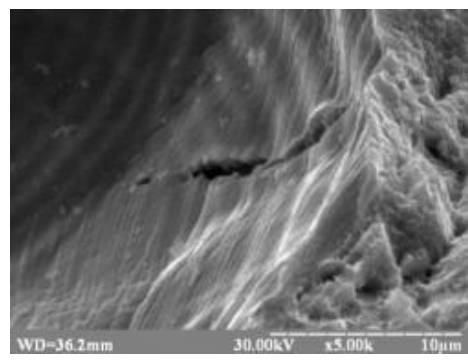

$\mathrm{c}$

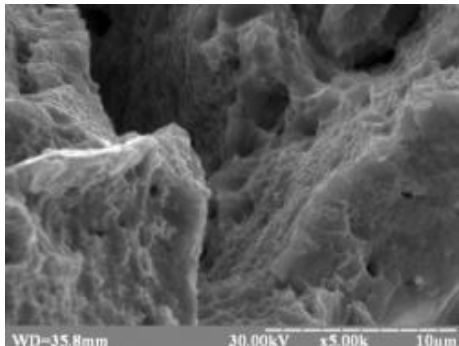

$\mathrm{f}$

Figure 8. Microfractograms of specimen 5 after tensile tests

The analysis of the continuity of the specimens material was performed by the microstructural method on the specimens heads metal by tension from the volume of the metal, which did not undergo deformation during the tensile test. The results are shown in Fig. 9. 


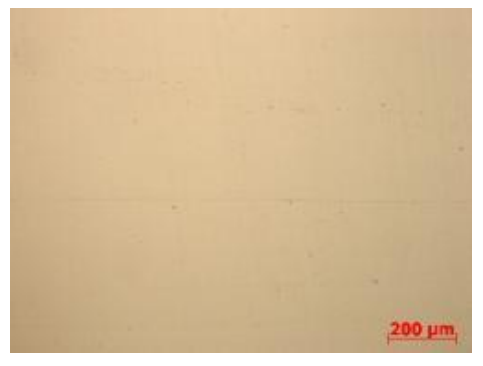

a

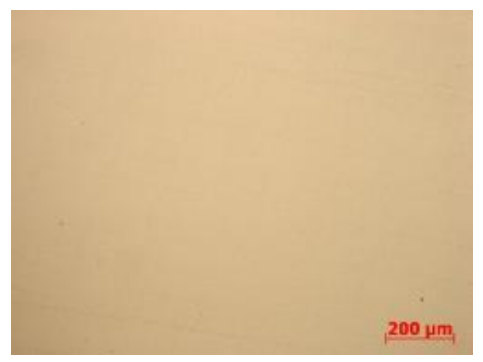

d

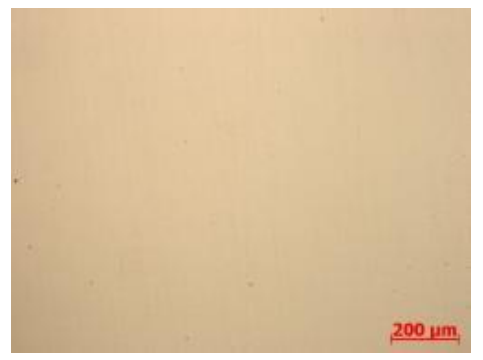

b

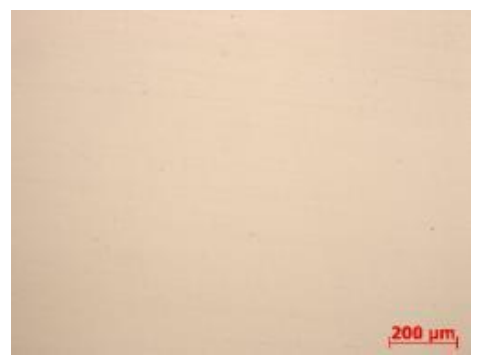

e

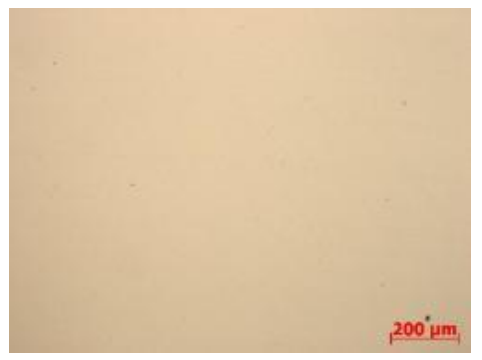

$\mathrm{c}$

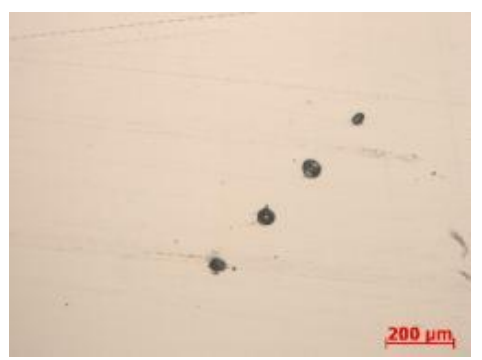

$\mathrm{f}$

Figure 9. Microstructure of experimental specimens: $\mathrm{a}-$ specimen $1, \mathrm{~b}-$ specimen $2, \mathrm{c}-$ specimen 3 , $\mathrm{d}-$ specimen $4, \mathrm{~d}, \mathrm{e}-$ specimen 5

When studying the metal of the test specimens in the polished state, it was found that the specimens $1-5$ had a high continuity (low porosity), a small number of oxide inclusions was observed. Specimens 4 and 5 have microvoids formed during printing, and they were noticed on the fracture surface of the specimen 5. Thus, the fracture revealed areas where load conditions and properties of the material as well as its ability to local destruction are combined in the most unfavorable way. Specimens 1-3 (horizontal) had no such defects, while the entire batch of prototypes was made in identical modes. Therefore, the process modes must be adjusted depending on the size of the cross-sectional area of the part. When printing vertical specimens, the next layer was melted after a short period of time and the previous layer was not cooled enough, so the bath of molten metal received excess heat and formed a microvoid of «keyhole» type.

In general, it can be concluded that for both horizontal and vertical specimens in the heat-treated state as well as in the raw fracture by a viscous mechanism occurred, as the typical pits are on the fracture surfaces of all specimens. Although the elongation in the state after 3-D printing without heat treatment is much higher than in the state after heat treatment, their fracture surfaces are fundamentally similar, and macrogeometry is viscous. The deepest relief was noticed after processing in the air-cooled mode after high-temperature annealing. The size and depth of the pits are proportional to elasticity, thus, the presence of deeper pits on the fracture surface indicates higher elasticity, which corresponds to the results of mechanical tests (Table 1). Such defects as microvoids did not cause significant reduction in the mechanical properties of the test sprcimens.

Conclusions. Additive technologies are the promising area for aerospace parts and components. It is revealed that the use of heat treatment makes it possible to increase the complex of mechanical properties of INCONEL 718, produced by SLM-technology. It is found that the orientation of the specimens produced by SLM-technology has less influence on the 
strength properties (up to 9\%). The elasticity values for specimens printed in horizontal and vertical positions can differ up to $28 \%$. It is shown that the cooling environment after heat annealing (water or air) before the aging operation affects the mechanical properties.

\section{References}

1. Adzhamskij S. V., Kononenko A. A., Podol'skij R. V. Simuljacija vlijanija ostatochnyh naprjazhenij i parametrov SLM-tehnologii na formirovanie oblasti granic izdelija iz zharoprochnogo nikelevogo splava INCONEL 718. Ministry of Education and Science of Ukraine The National Metallurgical Academy of Ukraine, Dnipro, 17-19 March, 2020. No. 1. P. 4-6. DOI: https://doi.org/10.34185/1991-7848.itmm. 2020.01.00 [in Russian].

2. Adzhamskij S. V., Kononenko A. A., Podol'skij R. V. Ispol'zovanie SLM-tehnologii v detaljah i uzlah aviacionno-kosmicheskogo naznachenija. 11 Vseukraïns'ka konferencija molodih vchenih "Molodi vcheni - 2020". 2020. No. 1. P. 6-9 [in Russian].

3. Adzhamskij S. V., Kononenko A. A., Podol'skij R. V. Issledovanie vlijanija rezhimov SLM-processa na kachestvo v oblasti kontura izdelij, mizhnarodna konferencija "Universitets'ka nauka - 2020". 2020. No. 1. P. 157-158. Rezhim dostupu do resursu: http://eir.pstu.edu/bitstream/handle/123456789/ $17421 / \%$ D0\%A3_\%D0\%BA\%D0\%B0\%D1\%8F\%20\%D0\%BD\%D0\%B0\%D1\%83\%D0\%BA\%D0\%B0 _2020_\%D0\%A2_1.pdf [in Russian].

4. Senkiv L., Chekurin V., Diakiv V. (2018) Mathematical modeling of residual stresses in spiral welded pipe. Scientific Journal of TNTU (Tern.), vol. 90, no. 2, pp. 12-18. https://doi.org/10.33108/visnyk_tntu2018.02.012

5. Adzhamskij S. V., Kononenko A. A., Podol'skij R. V., Razrabotka tehnologii izgotovlenija izdelij dlja aviacionno-kosmicheskoj tehniki metodom vyborochnogo lazernogo plavlenija. Materiali XII Mizhnarodnoï naukovo-tehnichnoï konferenciï "Novi materiali i tehnologiï v mashinobuduvanni”. 2020. Rezhim dostupu do resursu: https://foundry.kpi.ua/wp-content/uploads/2020/06/conferenziya_2020.pdf\# page $=29$ [in Russian].

6. Adzhamskii S. V., Kononenko A. A. Investigation of deep penetration conditions when making specimens from high-temperature alloy Inconel 718 by the method of selective laser melting. Avtomaticheskaya Svarka (Automatic Welding), no. 6, 2019, pp. 65-70. [In Russian]. https://doi.org/10.15407/as2019.06.11

7. Adzhamskij S. V. Realizacija SLM - tehnologii dlja izgotovlenija obrazcov iz zharoprochnogo splava INCONEL 718, primenjaemogo v aviacionno-kosmicheskoj tehnike. Aviacionno-kosmicheskaja tehnika i tehnologija. No. 2 (154). 2019. [In Russian]. https://doi.org/10.32620/aktt.2019.2.09

8. Adzhamskij S. V., Kononenko A. A., Podol'skij R. V. Dvumernoe modelirovanie nestacionarnogo temperaturnogo polja edinichnogo treka iz zharoprochnogo splava INCONEL 718. Materiali vseukraïns'koï naukovo-metodichnoï konferenciï "Problemi matematichnogo modeljuvannja". 2020. No. 1. P. 42-45. Rezhim dostupu: https://www.dstu.dp.ua/uni/downloads/material_konf_traven_\% 202020.pdf [in Russian].

9. Parusov E., Sychkov A., Gubenko S., Ambrazhey M. (2016) Vplyv boru na formuvannia efektyvnoi struktury buntovoho prokatu i pidvyshchennia yoho tekhnolohichnoi plastychnosti pry volochinni [Influence of boron on forming efficient structure of rolled steel and increase its technological plasticity at drawing]. Scientific Journal of TNTU (Tern.), vol. 83, no. 3, pp. 99-108 [in Ukrainian].

10. Zhang D., Niu W., Cao X., Liu Z. Effect of standard heat treatment on the microstructure and mechanical properties of selective laser melting manufactured Inconel 718 superalloy, Mater. Sci. Eng. A 644 (2015). 32-40. https://doi.org/10.1016/j.msea.2015.06.021.

11. Zhang Y., Li Z., Nie P., Wu Y., Effect of heat treatment on niobium segregation of laser-cladded IN718 alloy coating, Metall. Mater. Trans. A Phys. Metall. Mater. Sci. 44 (2013). 708-716. https:// doi.org/10.1007/s11661-012-1459-z

12. Thomas G. Gallmeyera, Senthamilaruvi Moorthya, Branden B. Kappesa, Michael J. Millsb, Behnam AminAhmadia, Aaron P. Stebner. Knowledge of process-structure-property relationships to engineer better heat treatments for laser powder bed fusion additive manufactured Inconel 718. Additive Manufacturing 31 (2020) 100977. https://doi.org/10.1016/j.addma.2019.100977

\section{Список використаної літератури}

1. Аджамский С. В., Кононенко А. А., Подольский Р. В. Симуляция влияния остаточных напряжений и параметров SLM-технологии на формирование области границ изделия из жаропрочного никелевого сплава INCONEL 718. Ministry of Education and Science of Ukraine The National Metallurgical Academy of Ukraine (Dnipro, 17-19 March, 2020.). 2020. № 1. C. 4-6. DOI: 10.34185/1991-7848.itmm.2020.01.00. 
2. Аджамский С. В., Кононенко А. А., Подольский Р. В. Использование SLM-технологии в деталях и узлах авиационно-космического назначения: 11 Всеукраїнська конференція молодих вчених «Молоді вчені - 2020». 2020. № 1. С. 6-9.

3. Аджамский С. В., Кононенко А. А., Подольский Р. В. Исследование влияния режимов SLMпроцесса на качество в области контура изделий: міжнародна конференція «Університетська наука - 2020». 2020. № 1. C. 157-158. URL: http://eir.pstu.edu/bitstream/handle/123456789/17421/\% D0\%A3_\%D0\%BA\%D0\%B0\%D1\%8F\%20\%D0\%BD\%D0\%B0\%D1\%83\%D0\%BA\%D0\%B0_2020_\% D0\%A2_1.pdf

4. Senkiv L., Chekurin V., Diakiv V. Mathematical modeling of residual stresses in spiral welded pipe. Scientific Journal of TNTU. 2018. Vol. 90. No. 2. P. 12-18. https://doi.org/10.33108/visnyk_tntu2018.02.012

5. Аджамский С. В., Кононенко А. А., Подольский Р. В. Разработка технологии изготовления изделий для авиационно-космической техники методом выборочного лазерного плавления: матеріали XII Міжнародної науково-технічної конференції «Нові матеріали і технології в машинобудуванні». 2020. URL: https://foundry.kpi.ua/wp-content/uploads/2020/06/conferenziya_2020.pdf\#page=29.

6. Adzhamskij S. V., Kononenko A. A., Podol'skij R. V., Investigation of deep penetration conditions when making specimens from high-temperature alloy Inconel 718 by the method of selective laser melting. Avtomaticheskaya Svarka (Automatic Welding), No. 6, 2019, pp. 65-70. https://doi.org/10.15407/as2019.06.11

7. Аджамский С. В. Реализация SLM - технологии для изготовления образцов из жаропрочного сплава INCONEL 718, применяемого в авиационно-космической технике. Авиационно-космическая техника и технология. 2019. № 2 (154). 2019. Doi: 10.32620/aktt.2019.2.09.

8. Аджамский С. В., Кононенко А. А., Подольский Р. В. Двумерное моделирование нестационарного температурного поля единичного трека из жаропрочного сплава INCONEL 718: матеріали всеукраїнської науково-методичної конференції «Проблеми математичного моделювання». 2020. № 1. C. 42-45 URL: https://www.dstu.dp.ua/uni/downloads/material_konf_traven_\%202020.pdf.

9. Парусов Е., Сичков О., Губенко С., Амбражей М. Вплив бору на формування ефективної структури бунтового прокату і підвищення його технологічної пластичності при волочінні. Вісник ТНТУ. 2016. Том 83. № 3. C. 99-108.

10. Zhang D., Niu W., Cao X., Liu Z. Effect of standard heat treatment on the microstructure and mechanical properties of selective laser melting manufactured Inconel 718 superalloy: Mater. Sci. Eng. A 644 (2015) 32-40. https://doi.org/10.1016/j.msea.2015.06.021

11.Zhang Y., Li Z., Nie P., Wu Y. Effect of heat treatment on niobium segregation of laser-cladded IN718 alloy coating, Metall. Mater. Trans. A Phys. Metall. Mater. Sci. 44 (2013), 708-716. https:// doi.org/10.1007/s11661-012-1459-z

12. Thomas G. Gallmeyera, Senthamilaruvi Moorthya, Branden B. Kappesa, Michael J. Millsb, Behnam AminAhmadia, Aaron P. Stebner. Knowledge of process-structure-property relationships to engineer better heat treatments for laser powder bed fusion additive manufactured Inconel 718. Additive Manufacturing 31 (2020) 100977. https://doi.org/10.1016/j.addma.2019.100977 
УДК 658.52

\title{
МЕХАНІЧНІ ВЛАСТИВОСТІ ЖАРОМНЦНОГО СУПЕРСПЛАВУ INCONEL 718, ОТРИМАНОГО СЕЛЕКТИВНИМ ЛАЗЕРНИМ ПЛАВЛЕННЯМ ТА ТЕРМІЧНИМ ОБРОБЛЕННЯМ ЗА РІЗНИХ НАПРЯМІВ НАВАНТАЖЕННЯ
}

\author{
Сергій Аджамський ${ }^{1,2}$; Ганна Кононенко ${ }^{2,3}$; Ростислав Подольський ${ }^{2,3,4}$ \\ ${ }^{1}$ Дніпровський національний університет імені Олеся Гончара, \\ Дніпро, Украӥна \\ ${ }^{2} L L C$ «Additive Laser Technology of Ukraine», Дніпро, Україна \\ ${ }^{3}$ Інститут чорної металургї імені 3. І. Некрасова НАН України, \\ Дніпро, Україна \\ ${ }^{4}$ Національна металургійна академія України, Дніпро, Украйна
}

\begin{abstract}
Резюме. Адитивне виробництво - це перспективний сучасний напрям, який дозволяє швидко $i$ з високою точністю пошарово виготовляти складнопрофільні вироби за комп'ютерною моделлю практично з будь-яких металевих порошків. Роботу присвячено дослідженню впливу орієнтачї зразка при 3-D друку і режсмів термічної обробки на механічні властивості зразків, виготовлених з жароміцного нікелевого сплаву Inconel 718, виготовленого за SLM-технологією. При дослідженні впливу положення зразка при друці було встановлено, щзо показники міџності незначно вищі для вертикальних зразків (до 9\%), а пластичність нижча в середньому на 20\%. Після стандартної термічної обробки, яка складається з двох стадій (гартування та старіння) з охолодженням на спокійному повітрі показники міцності вертикально й горизонтально побудованого зразків дуже близькі (різниця становить до 3\%). Показники пластичності для горизонтального положення зразка при друці вище на 10\% і 30\%. За макрогеометрією досліджувані зразки мають чашковий злам, за мікрофракторамами встановлено, ще механізм руйнування в'язкий та квазікрихкий. У початковому стані, який формується при 3-D друиі, спостерігалися ознаки в'язкого руйнування: тріщина розповсюджується в основному шляхом поділу металу по площинах, які не збігаються з кристалографічними площинами ділянок. В основному поверхня їх руйнування у вигляді ямок, мікрозаглибин на поверхні руйнування, щзо являють собою розкриті поверхні мікропорожнеч, які утворилися в проиесі пластичної течї̈ металу. При дослідженні металу дослідних зразків у полірованому стані встановлено, щуо зразки № 1-5 мали високу суцільність (низьку пористість), спостерігали невелику кількість оксидних включень. Встановлено, що наявність дефектів у вигляді мікропор не призвела до істотного зниження механічних властивостей дослідних зразків.
\end{abstract}

Ключові слова: SLM-технологія, Inconel 718, термічна обробка, орієнтація зразка, мікрофрактограма, механічні властивості. 